DOI : http://10.24260/khatulistiwa.v10i1.1701

\title{
THE INSTRUCTIONAL MANAGEMENT ON SOFT SKILLS IN ISLAMIC PERSPECTIVE: A MULTI-CASE STUDY AT SEKOLAH KARAKTER INDONESIA HERITAGE FOUNDATION (IHF) AND BRAWIJAYA SMART SCHOOL (BSS)
}

\author{
Aries Munandar \\ UNIRA Malang, Indonesia. Email; raries@gmail.com
}

\section{HIGHLIGHT}

- IKI SAE MAS. IKI SAE stands for Initiative, Creative, Innovative, Sensitive, Applicative, and Effective, Meanwhile, MAS is "Menyatunya Al Quran and Sunnah" or the fusion of Al-Quran and Sunnah within Muslim personality

\section{ARTICLE HISTORY}

$\begin{array}{lll}\text { Submit } & : & \text { Apr 24, } 2020 \\ \text { Revision } & : & \text { Apr 28, 2020 } \\ \text { Revision } & : & \text { May 12, } 2020 \\ \text { Minor } & & \\ \text { Accepted } & : & \text { May 8, 2020 } \\ \text { Published } & : & \text { May 18, 2020 }\end{array}$

The study employs qualitative research method with multiple case study design, in which a meaning making activity is underlined as the first objective of interpretive research in understanding social phenomena of education activities. The phenomena of soft skillsoccurs in real-life events andcurrent situation, as well as programs and activities. In this qualitative research method the researcher conducted three main activities such as in-depth interview, observation and to get relevant data collection in order to enrich and complete the previous obtained data. Based on findings, it is known substantively that students' soft skills will not be developed if the instructional management focuses on academic. Besides, soft skills will enhance significantly students' academic results, because soft skills will enable and improve students' potentials to reach the best learning achievement. In Islamic perspective, the quality of soft skills within akhlak-adab domain will be more better if soft skills' development are referred to a sound heart (qolbun salim).

Keyword : $\quad$ Instructional Management, Soft Skills, Elementary Education, Soft Skills in Islamic Perspective.

Copyright@2020 The Authors. Published by The Institute for Research and Community Service Pontianak State Institute for Islamic Studies This is an Open Access article under of CC BY-NC-ND 4.0 License https://creativecommons.org/licenses/by-nc-nd/4.0

KHATULISTIWA: Journal of Islamic Studies Vol. 10, No. 1. March 2020
DOI: http://10.24260/khatulistiwa.v10i1.1701 The Instructional Management on Soft Skills in Islamic Persepctive: A Multi-case Study at Sekolah Karakter... 


\section{A. INTRODUCTION}

The Prophet Muhammad was sent to earth is to solely enhance human morals (Hadith). Noble behavior, positive behavior and spreading good for others and environment are actually the teaching of Islam so that Islam is actually as a religion of practices. On the other hand, understanding Islam should be embodied in the forms of goodness. The cornerstone of the good deeds that is done in Islam must come from precepts in the Koran and Hadith.

Through education, the quality of human resources can be optimally improved, realizing the advanced civilization of mankind. The reliability of education welfare result on people could be witnessed in the country concern on the quality and quantity of education. Educational success spawned the successful performance of a person.

However, the International Association for the Evaluation of Educational Achievement (IAEA) published its findings on students learning achievement in many countries in the world. In fact, the reading ability of Indonesian Elementary School (SD) students is ranked $26^{\text {th }}$ out of 27 countries. Out of 38 countries, the mathematical ability of Indonesian junior high school (SMP) students is ranked 34th. The learning achievement of the SMP students on natural science is ranked $32^{\text {th }}$ out of countries (Raka Joni, 2005)

The teaching and learning process in schools mainly emphasizes the cognitive aspect of humankind. Ujian Nasional (UN) or the National Examination is used as the predictor of students' learning achievement. Therefore, lots of efforts and energy are fully deployed for the success of the UN implementation which is merely stressing on academic or technical skills.

In addition, the Education Law has actually focused on the importance of Akhlak mulia (noble behavior) as it is also the objective of the national education system. The noble behavior is derived from virtue of soft skills as well as emotional intelligence. Thus, soft skills improvement is really becoming our main concerns of the educational stakeholders both in micro and macro perspectives because, nowadays we see rampant negative behaviors such as, corruption, cheating, and indiscipline manners are happened in many places and evenly distributed, at certain cases even the said manners are undertaken by educated people.

KHATULISTIWA: Journal of Islamic Studies Vol. 10, No. 1. March 2020
DOI: http://10.24260/khatulistiwa.v10i1.1701 The Instructional Management on Soft Skills in Islamic Persepctive: A Multi-case Study at Sekolah Karakter... 


\section{The Phenomenon of Education and Human Development in Indonesia}

In Indonesia, the new national curriculum 2013 is just implemented at the certain schools this year 2013. This curriculum has actually appropriate orientation to the character development of students at primary and secondary education level. However, in applying this good concept the Ministry of National Education should be also upgrading the teachers' competency, otherwise the defined educational goals in achieving good personal characters of students will not happen.

Education development at primary or elementary school level (SD) and junior high school level (SMP) quantitatively have shown impressive achievement, especially since the President instruction (Inpres) prevailed in 1970s then the government launched nine years basic schooling policy (wajib belajar) for the young school age. But, the improvement in quantity it does not mean in line with its education quality, because the findings show that learning achievement of students does not good enough. The low quality of schools' graduates is caused the traditionally of teaching and learning process in which teaching activity becomes a transfer of knowledge and or forwarding information only. A teacher justto deliver directly the content oftextbook in classroom as is. This activity addresses cognitive skills only in lower level of thinking namely memory, drilling and retention.

The Education process in schools mostly is carried out by forwarding information and informing the texts of books only (Raka Joni, 2005). Teaching and learning in schools or educational institutions are mostly still emphasizing cognitive sides of humankind with the National exams or Ujian Nasional (UN) as predictor on student learning achievement. In Indonesia, lots effort and energy are fully deployed for the success of UN implementation. As a matter of fact, UN is merely stressing on academic-hard skills. In other words, the development of non-academic soft skills is seemingly neglected.

The reform era that has been started since 1998 in Indonesia actually was aimed to do reconstruction in many sectors of the national systems including educational aspect but such progress is actually still far away from our expectation. Deteriorated multi-dimensional problem spreads in many aspects in the form of corruption, mass violence, and other reprehensible behaviors. The phenomenon above indicates something wrong with our human development (read: education) practices.

KHATULISTIWA: Journal of Islamic Studies Vol. 10, No. 1. March 2020
DOI: http://10.24260/khatulistiwa.v10i1.1701 The Instructional Management on Soft Skills in Islamic Persepctive: A Multi-case Study at Sekolah Karakter... 
In developed countries, socio-education systems take a strategic role in developing national character as well as well-being people. Human development system is built not only based upon academic-hard skills but more than that is based on soft skills. Hence, in a social context morality is the main trait to be developed. If there is a social leader with bad attitude, the public will not accept him/her and certainly will no longer be deemed as a leader.

Elites or leaders may be successful in academia but if they behave in a way that run counter to social morality, then public will automatically, reject them. This is because people in developed countries respect noble behavior and soft skills on top of solely intellectual skills. This phenomenon commonly occurs in many aspects of life. The education system and social mechanism to foster virtues of people have been already in place. It means the teaching and learning process in a class of formal education as well as people interaction in a social context beyond the schools always placing soft skills of human development as their main concern.

The objective of national education, as stipulated in Chapter 3 of National Education System Law No. 20/2003 is to nurture students' potential to have faith in God, develop good character, live healthy life and to be knowledgeable, creative, self-reliant, responsible and democratic citizens. The objectives of Indonesia's education are ideally the creation "good and righteous men and women" who believe in God, has a noble character, mastery of science, technology, arts in order to advance a prosperous and civilized society based on the state ideology Pancasila and the 1945 Constitution.In other words, with respect to its aims, our national education already envisions instilling Indonesian citizens with human values. Those values are indicators of insan kamil, or a perfect and holistic people (UU Sisdiknas).

Many people are awed by academic achievement. A good school is equated with academic result or a successful school is measured by the total number of students passing the national exams or Ujian Nasional (UN).The UN exams are not a proper tool to be used in evaluating students' learning achievements because they are not tests fit for everyone. They measure on the cognitive side of human intellect.From public view point, the favorite or most famous schools are often judged by these criteria and people proud about it (Aris Munandar, 2015). Nowadays, the Indonesian Government has allocated quite very much budget for education sector which is bigger than before. Despite this budget has reached $20 \%$ of the national expense and income budget, however, such amount is not only for improving the

KHATULISTIWA: Journal of Islamic Studies Vol. 10, No. 1. March 2020
DOI: http://10.24260/khatulistiwa.v10i1.1701 The Instructional Management on Soft Skills in Islamic Persepctive: A Multi-case Study at Sekolah Karakter... 
process of teaching and learning but also for the administrative expenses in a big portion. Therefore, the quality enhancement of teaching and learning process is still facing obstacle.

\section{Problematic Educational Management: Indonesia Context}

In educational management the role of man is very important because the work of management itself always deals with different kinds of people. Therefore, school principal as a manager should be equipped with appropriate soft skills (SS). At the same thing the educationalists like teachers as well as lecturers should also be furnished with their well SS in order to improve the students' SS quality.

In Indonesia, the term management of educational management replaced the term administration of educational administration. Then, the educational management has been taught around two decades ago as a new subject within the teachers' education institute (IKIP). However, at some extent we find that the terms educational management and educational administration can be used interchangeably. Researchers prefer to use the term educational management that implies broad meaning, as such educational management consists of instructional management, personnel management, finance management, school and public relations, curriculum management, student management, etc. On the other hand, the term management itself is derived from Italian word managiare, it means to train horse (William Mantja, 2010). Identically, people who can manage education as the same with people who can train horse well, it implies good management competency. The management consists of several functional areas such as planning, organizing, actuating and controlling. The instructional management as a compartment of educational management also applies such four areas of management: planning; organizing, actuating and controlling. Teacher who is the ownership of instructional management should be competent in dealing with the activities of planning, organizing, actuating and controlling in order to maximize the result of learning achievement.

Instructional management activity in educational institutions ought to be based on its institution's curricula which derived from the national curriculum. Based on aforementioned explanation, the education goal and objectives of the school's curricula must be derived from the purpose of national education itself which is to develop student's potentialities to become

KHATULISTIWA: Journal of Islamic Studies Vol. 10, No. 1. March 2020
DOI: http://10.24260/khatulistiwa.v10i1.1701 The Instructional Management on Soft Skills in Islamic Persepctive: A Multi-case Study at Sekolah Karakter... 
a man with taqwa (God fearing-awareness, piousness and piety), performing noble behavior, healthy, knowledgeable, competent, creative, independence and become democratic and responsible citizen. ${ }^{1}$ This law stipulates as reference prior to set up educational curriculum in Indonesia. Theoretically, every school curriculum should always refer to the law, National Education System. ${ }^{2}$

Students (learners) in school should follow a-defined programs which so-called school curriculum. Teaching and learning activities are based on this curriculum. The school curriculum management as a part of the educational management should be also based on the aims of the said national education. The education goal and objectives of school curriculum are derived from the national education aims which are to develop students' potentialities and capabilities for becoming good people in hard skills and soft skills. From the ten students' skills mentioned in the education aim we can classify into two categories, namely academic-hard skills which are; knowledgeable and competent and non academicsoft skills which are; believe in and fear God, noble behavior, healthy, creative, independent, democratic and responsible). It means that to develop student soft skills is already in place and written in the national education objective as aforementioned above.

Elementary education level is very crucial for further education in secondary education as well as higher education (university) levels. Inappropriate teaching treatment or instructional management incompetence in basic education either in pre-schools, PAUD (Pendidikan Anak Usia Dini), primary or elementary schools (Sekolah Dasar) will result bad and worse quality in further education. Pupils or students will perform unexpected learning behavior. The study done by Howard Gardner which as elucidated by Endin Mujahidin (2012) found that the errors or mistakes in education system in childhood era can be of negative affect to the children creativity. In consequence, this decline situation will continue until they reach the age of 40 years. ${ }^{3}$ Mainstream schools at elementary education always manage its teaching and learning activities emphasize mostly on cognitive domain rather than socio-emotional aspects. In fact, many developed countries have been revitalized their orientation in elementary education. Elementary schools in Japan, for instance, have reduced

\footnotetext{
${ }^{1}$ Pasal 3 Undang-undang Sistem Pendidikan Nasional No. 20 Tahun 2003

${ }^{2}$ SuharsimiArikunto\& Lia Yuliana, ManajemenPendidikan (Yogyakarta: Aditya Media, 2009: 133).

${ }^{3}$ Endin Mujahidin, et.al., 2012. Developing Character Education Quality in Eelementary School.
}

KHATULISTIWA: Journal of Islamic Studies Vol. 10, No. 1. March 2020
DOI: http://10.24260/khatulistiwa.v10i1.1701 The Instructional Management on Soft Skills in Islamic Persepctive: A Multi-case Study at Sekolah Karakter... 
hours of mathematics and science and instead of it they add more hours for enhancing students' personality character. ${ }^{4}$

The main focus of this research is about students' soft skills in Indonesia which is still at low level performance as the indicators has been delineating in the beginning of this writing. Meanwhile, the quality of education results as the aims of national educational is clearly mentioned as stipulated in Chapter 3 of National Education System Law No. 20/2003 that is to nurture students' potential to have faith in God, develop good character, live healthy life and to be knowledgeable, creative, self-reliant, responsible and democratic citizens. It means that all activities in teaching and learning should support the achievement of such expected behaviors as aforementioned ${ }^{5}$.

However, there is a gap between national education policy and the implementation of such policy in schools. Anarchy attitudes become most frequent or common in education. More worryingly, acts of violence involving students became more prevalent when character education was integrated into the school curriculum. ${ }^{6}$ Therefore, these cases should prompt us to revisit the current system of character education in particular. Do we teach them the right things? What is wrong with the teaching and learning process? Some education experts believe that character education in the school curriculum may be needed to address the problem. The Education itself should be addressed to reach determined students' new behavior as expected in the curriculum of educational institution (school) which is derived from the national curriculum.

Based on context and focus of research above, an overarching question guides this inquiry. The central question asks: how the soft skills education is managed in the elementary schools and how responsive is it to the soft skills nature of schools' management. The next question is, what are the teachers, principal, other education stakeholders' perception in understanding soft skills concept?

\footnotetext{
${ }^{4}$ RianeEisler in RatnaMegawangi, PendidikanHolistik, page 28 and several Aries' articles on Education

${ }^{5}$ UU Sistem Pendidikan Nasional (the National Education Law of Indonesia) No. 200/2003 Chapter 1 and 2

${ }^{6}$ Aries Musnandar. Indonesia: A Country of Challenge. UB Press. Malang, 2014: p. 57-59

KHATULISTIWA: Journal of Islamic Studies

Vol. 10, No. 1. March 2020 


\section{B. METHOD}

A qualitative method was chosen for this research as the best approach to this type of research. The multi case study type of qualitative research is used in a way to obtain an indepth understanding of a particular social context (Mudjia Rahardjo, 2015). The study attempts to link up to four categories and scopes of curriculum management such as core curricular, intra curricular, extra-curricular, and non-curricular. Researchers conduct case studies in order to describe, explain and evaluate particular phenomena (Gall \& Borg, 2005). Besides, soft skills understanding of teachers and school principals would be delineated in this study which is obtained from interview, observation results and study documentation. This research is intended to introduce a new approach that important for improving the quality of education, especially in the level of elementary schools. The results of this research are expected to divert or shift the perspective and mindset of educators as well as education policy makers about the concept of the successful achievement of the performance (students' performance achievement). The success of the performance of students begins with paying attention to the implementation of the concept of soft skills in school. This research uses qualitative methods and research sites are in SD Karakter Indonesian Heritage Foundation (IHF) and SD BSS (Brawijaya Smart School).

In Indonesia, the mainstream schools always manage its teaching and learning activities emphasizing on the cognitive domain rather than the socio-emotional aspects. In fact, a number of developed countries have revitalized their orientation in elementary education. Long before this, many people perceive the success of a person's performance associated with the level of IQ (Intelligence Quotient). The higher a person's IQ score, according to the original assumptions, the more "successful" life. Lately, a number of interesting findings showing that there is other aspect that play important role and become someone's critical success factors. The other aspect is called the Emotional Intelligence (EI). These findings suggest that intelligence can be expanded not only in the form of intellectual ability, but also emotional skills. Moreover, from a variety of research and observation of practice in the corporate world, there is a significant relationship between emotional competence and success in displaying the best performance (top performers). Apparently, EI contributes about $80 \%$ to the factors determining life, while $20 \%$

KHATULISTIWA: Journal of Islamic Studies Vol. 10, No. 1. March 2020
DOI: http://10.24260/khatulistiwa.v10i1.1701 The Instructional Management on Soft Skills in Islamic Persepctive: A Multi-case Study at Sekolah Karakter... 
of contribution was only from IQ or intellectual ability (Daniel Goleman, 1995, 1998). This does not mean that IQ is not important as it is required to master academic skills or technical competencies (hard skills). IQ is often associated with a person's intellect. Meanwhile, EI (Emotional Intelligence) is often associated with human skills. Therefore, the people performance quality can essentially be categorized into two namely technical competencies (hard skills) and non-technical competencies (soft skills). There are some people who regard soft skills solely as people skills. This actually does not entirely true because soft skills are not only people skills. It may be true that the higher people quality on soft skills, the higher hard skills that people may get. However, the concept of soft skills always has interchangeable position with other terms such as non-technical competence, emotional intelligence and personal skills which consists of intra-personal and inter-personal.

In the life of the nation, educational concept applied in Indonesia should refer to the 1945 Constitution which was then in the elaboration of the Law on National Education System (UU SPN) no. 20 in 2003. Chapter 2 of article 3 of UU SPN has included the importance of human skills (read: soft skills) for growing-developing at learner's potency. There are at least eight aspects of soft skills that need to be considered in the process of education in Indonesia, namely: faith and pious, noble character, healthy, creative, independent, democratic and responsible. The Eight- aspect is part of soft skills. While hard skills or academic aspect is only represented in two aspects: a knowledgeable and competent.

The objectives and directions of national education formally refer to the mandate of the 1945 Constitution and the philosophy of the nation in the values of Pancasila that is not at odds with the universal values of Islam. UU SPN as elaborations of the values of the above is already pretty well laid the eight-aspect of soft skills as part of the functioning of the potential learners in the national education system in Indonesia

\section{RESULT \& DISCUSSION}

\section{The Inter-Case Research Finding at SD Karakter and SD BSS}

Based on data exposure and research findings, it is extended to the analysis of intercases of SD BSS and SD Karakter IHF. The findings as below:

KHATULISTIWA: Journal of Islamic Studies Vol. 10, No. 1. March 2020
DOI: http://10.24260/khatulistiwa.v10i1.1701 The Instructional Management on Soft Skills in Islamic Persepctive: A Multi-case Study at Sekolah Karakter... 


\subsection{Soft Skills Concept \& Development}

Soft skills concept from the eyes of principal, teachers and other educationists of SD BSS is identical with character concept. Therefore, they regard soft skills as good personal behavior like respect others, telling the truth, discipline and other good deeds. They do not elaborate the concept of soft skills as professional acumen such as to overcome with problem.

Personality development is regarded also as character education. Additionally, at some extent they include extracurricular or non-academic activities in school as character education and accordingly of course soft skills development, which eventually is deemed by school as continuation program of character education. Religious and PPKn (Civics Education) are the main subjects to develop concept of character into practice. Briefly, soft skills concept for BSS is equal to character education.

On the other hand, at IHF schools soft skills concept is the same meaning with the character concept. The model of Character-Based Holistic Education (CBHE) is a concept of IHF SD Karakter in understanding soft skills concept. This model has been applied to their TK and SD Karakter.

The CBHE model applies some theories of social, emotional, cognitive, physical, moral, and spiritual. It is expectedly that every pupil will be growing well in spiritual, intellectual, social physical, emotional, creative thinking and taking responsibility as well as to become independent person. At SD Karakter of IHF the program of CBHE is more complete and details rather than SD BSS. IHF becomes pioneer by creating a model of holistic education for elementary level of education with the best quality.

This model is an effort to conduct holistic character education by involving aspects of knowledge, feeling, loving and acting to the children.

Meanwhile, many existing kindergartens and elementary schools in Indonesia practice harmful pedagogies, such as harsh teaching, too much academic pressure and little attention on child's socio-emotional development. Therefore, IHF is ready to help the existing public schools to adopt the model of Character-Based Holistic Education (partnerships with sponsors for schools in poor communities).

The chairperson of IHF is convinced that CBHE model can improve students' soft skills, awhile BSS has no such a kind of program. As the public school BSS cannot free

KHATULISTIWA: Journal of Islamic Studies Vol. 10, No. 1. March 2020
DOI: http://10.24260/khatulistiwa.v10i1.1701 The Instructional Management on Soft Skills in Islamic Persepctive: A Multi-case Study at Sekolah Karakter... 
enough to create a special program like what IHF did. The education government policy for mainstream schools is quite strict and must be followed submissively.

\subsection{The Concept on Character Education}

The school principals and supervisor agree with popular concept playing while learning instead of playing is learning. The teaching and learning activities in schools are directed to accomplish certain education objectives. The character education is interpreted as in line with soft skills development. But, they limit the meaning of soft skills to noble behavior or relates to interpersonal skills such as communicate with others, discipline, respect others (including older people), tell the truth, help each other, and other related noble behaviors. In this understanding, they separated the connection between soft skills and hard skills.

The character traits as mentioned above do not have direct relation with hard skills. Therefore, the result of hard skills performance is different from the result of character performance. The principals and supervisor perceived that character education cannot lead directly to better academic skills, because character is about the daily behavior or interaction with others. It has nothing to do with academic achievement, known as non-academic skills. They thought characters and soft skills are intertwined. They regard soft skills as character of behavior only.

Based on their views, soft skills development could be done through extra curricular activities and they attach soft skills program within the subject matter. They believed that soft skills are similar to the character education which emphasizes much on the rapport skills rather than on developing real soft skills such as creative and innovative activities. The problem solving power, the personal effectiveness, tactfully solution skills are not in the character domain due to different circumstances. From this perspective, they assume that character education is different from academic performance result. This perception arises because they include non academic skills such as dancing, sport, and arts as character performance. On the other hand, they also call the character education as personality development. Briefly, character education is an effort to enhance students' moral and norms closer to the religious values.

KHATULISTIWA: Journal of Islamic Studies Vol. 10, No. 1. March 2020
DOI: http://10.24260/khatulistiwa.v10i1.1701 The Instructional Management on Soft Skills in Islamic Persepctive: A Multi-case Study at Sekolah Karakter... 


\subsection{Teacher Perception on Soft Skills}

A teacher's perception creates teacher's conception on soft skills (SS). It means that if a school teacher is having incorrect perception on SS, then it will automatically mislead him/her to the conception of SS. The perception of SS is an important point for school teacher at the beginning, prior to construct a conception of SS itself. Once the conception is correct, we may arrange the suitable development programs. The good learning programs of SS will be effectively implemented when a school has very good conception on SS. Otherwise, the process of learning program may create unexpected objectives.

Perception is the ability to see, hear, and become aware of something through the senses. Hence, the perception is a way of regarding, understanding, or interpreting something; a mental impression. ${ }^{7}$ After getting common perception, a man may construct concept in the form of abstract idea, to build framework of something is perceived. In general, a framework is conceptual structure that is intended to serve as a guidance for building something that expands the structure into something useful. ${ }^{8} \mathrm{~A}$ framework is elaborated with learning activities to achieve the goals.

SS conception at the common teachers' perception will bring similar platform in implementing program. By clear vision and mission that are embedded in teachers' mind; a school could achieve the defined goals. In terms of SD BSS case, SS conception is built upon the ability of every teacher to understand the concept.

\subsection{The Role and Influence of Top Level Management}

In management concept, the role and influence from top level person within an organization is important. Without any direction and supervision from the top level person, it will be impossible to get better result. Supervision tasks can be done by top level management in school. According to Glickman, the supervisor's tasks are not only taken by the principal, but also by subject area specialist, assistant principal, chairperson, head teacher or central office consultant. 9

7 https://www.google.com/search?q=aries+musnandar\&ie=utf-8\&oe=utf-8\#q=perception retrieved on November 17, 2015.

${ }^{8}$ http://whatis.techtarget.com/definition/framework, retrieved on November 17, 2015.

${ }^{9}$ See Glickman, 2004. Developmental Supervision, p.17

KHATULISTIWA: Journal of Islamic Studies

Vol. 10, No. 1. March 2020
DOI: http://10.24260/khatulistiwa.v10i1.1701 The Instructional Management on Soft Skills in Islamic Persepctive: A Multi-case Study at Sekolah Karakter... 
The influence of leadership that is applied by Ratna Megawangi to all teachers and staff significantly has been occurring for long time. This influence of leadership creates good performance result of students' SS as well as to direct teachers to have better teaching approach. Some researchers have shown that IHF graduates have been performing better characters than other school graduates.

The central element of applied management in various sectors is the top level people in an organization. Manager, leader and top level people in an organization are the key to get better performance results. The higher level person in a management process will have higher influence than others to achieve organization objectives. In this context, Ratna Megawangi, for instance, has proved her influence in the school performance.

Top level people involvement in applied management is primarily needed to get better process and results. This is because management is a process that involves humankind and to apply human approach. The leadership is driven by man to encourage people (subordinates) to work as expected by the organization.

\section{Proposition from Inter-Case Findings}

Propositions obtained from case research findings of SD Karakter IHF and SD BSS upon the development of soft skills through educational management practices in a school are explained as below:

a) The educationists' mindset of educators on soft skills conception should correct and have the common ground of perception.

b) Socialization is needed in two folds. First is to bring educationists (school principal, teachers, etc) in one perspective to understand the educational philosophy, purpose, management, evaluation and the interrelated things in formal education prior to

c) implement any specific program. Second, it is through a socialization activity; the program owner may have diagnostic problem in advance so that correction or fine tuning of such program is necessary to be done.

d) The development of soft skills values within the students' personality will only be successful if all have internalized the soft skills values into their daily good practices and conducts.

KHATULISTIWA: Journal of Islamic Studies Vol. 10, No. 1. March 2020
DOI: http://10.24260/khatulistiwa.v10i1.1701 The Instructional Management on Soft Skills in Islamic Persepctive: A Multi-case Study at Sekolah Karakter... 
e) Curriculum is very important because that is a reflection of educational philosophy of school's concern, and as the mechanism by which its goals are attained. The effective curriculum will not tolerate with significant gap between school stakeholders' perception and its implementation.

f) A student academic performance will improve significantly when student is having appropriate soft skills in advance. The developing of skills is becoming important for student of early child education prior to have its academic skills. In contrast, there would be difficult to shape soft skills of student at the higher level if student has been taught and focused solely to academic skills for years.

g) Character education and or soft skills development are the neutral concept and may accept values vary, including from others beyond its society and culture. Therefore, the only sources that never change are the values of Islam (derived from Quran and Sunnah/Hadith).

h) Undertaking soft skills application in school is not without shortcomings, because not all teachers and stakeholders have the same perception on the right concept of soft skills.

\section{CONCLUSION}

Based on the research context, the data description, the research findings and the discussion of findings, the research results can be explained as follows:

- The Indonesian human resource is still in an unfavorable quality.

- Student character is the main issue in education due to reprehensible phenomena, unexpected behavior is shown frequently in public sphere.

- Unfortunately, soft skills are not properly considered in the existing school's curriculum. They (school and education stakeholders) focus more on intellectual or hard skills and academic achievements only.

- In fact, the students' academic achievements and students' soft skills (nonacademic) performance have not shown promising results, yet.

- Soft skills affect the hard skills quality. Therefore, students' soft skills will enable and enhance their academic achievement.

- The soft skills development programs will bridge the gaps in social life.

- The teacher and principal should have the right perception and understanding on soft skills concept that can enhance the students' academic achievements

KHATULISTIWA: Journal of Islamic Studies Vol. 10, No. 1. March 2020
DOI: http://10.24260/khatulistiwa.v10i1.1701 The Instructional Management on Soft Skills in Islamic Persepctive: A Multi-case Study at Sekolah Karakter... 
- Special soft skills development programs for teachers and principal on SS are also important to be held in schools.

- The transmission methods for soft skills development programs can be upheld through hidden and / or formal curriculum. The hidden curriculum is a side effect of a teaching and learning activity and broader implicit concept. In hidden curriculum soft skills are not designed specifically into subjects.

Recommendations from this research results led to the need for teachers to understand the concept of soft skills properly, before designing a learning program that enables the development of students' soft skills quality optimally. In this case, the researcher proposes formula called the development of soft skills IKI SAE MAS. IKI SAE stands for Initiative, Creative, Innovative, Sensitive, Applicative, and Effective.

Meanwhile, MAS is "Menyatunya Al Quran and Sunnah" or the fusion of Al-Quran and Sunnah within Muslim personality. Thus, according to the researcher, the performance-based soft skills in Muslim students are the embodiment of such IKI SAE MAS formula.

\section{Epilog (Closing Notes)}

Based on the explanations above, let the researcher categorizes the virtue of soft skills into specific attributes such as initiative, creative, innovative, sensitive, applicative and effective. In order to enhance these six attributes we should; provide well managed and best practices of education and social activity; create system entails the appropriate laws, proper regulation and good examples from leaders (elites). Additionally, the conducive milieu is needed to let such phenomena occurs. Finally, all attributes and conditions mentioned above must be put and placed under the guidance of Sunnah and Al - Qur'an. The word initiative means the power or ability to begin or to follow energetically with a plan or task; enterprise and determination. A beginning or introductory step; an opening move: took the initiative in trying to solve the problem or an individual's action that begins a process, often done without direct managerial influence. ${ }^{10}$ The word creative has a meaning to create or to make something from nothing, while the word innovative is in line with the progress what has already been created and the modification of the existing one.

The word sensitive describes someone that responds quickly to external forces, be able to understand other people's feeling and problems. Then, applicative means capable of being

\footnotetext{
10 Read: http://www.businessdictionary.com/definition/initiative.html\#ixzz1sFiCr8Lz and also http://www.businessdictionary.com/definition/initiative.html. , retrieved on April 24, 2012

KHATULISTIWA: Journal of Islamic Studies Vol. 10, No. 1. March 2020

DOI: http://10.24260/khatulistiwa.v10i1.1701 The Instructional Management on Soft Skills in Islamic Persepctive: A Multi-case Study at Sekolah Karakter... 
applied or used. Meanwhile, effective is capable of producing intended results ready for service, work well as a means. ${ }^{11}$

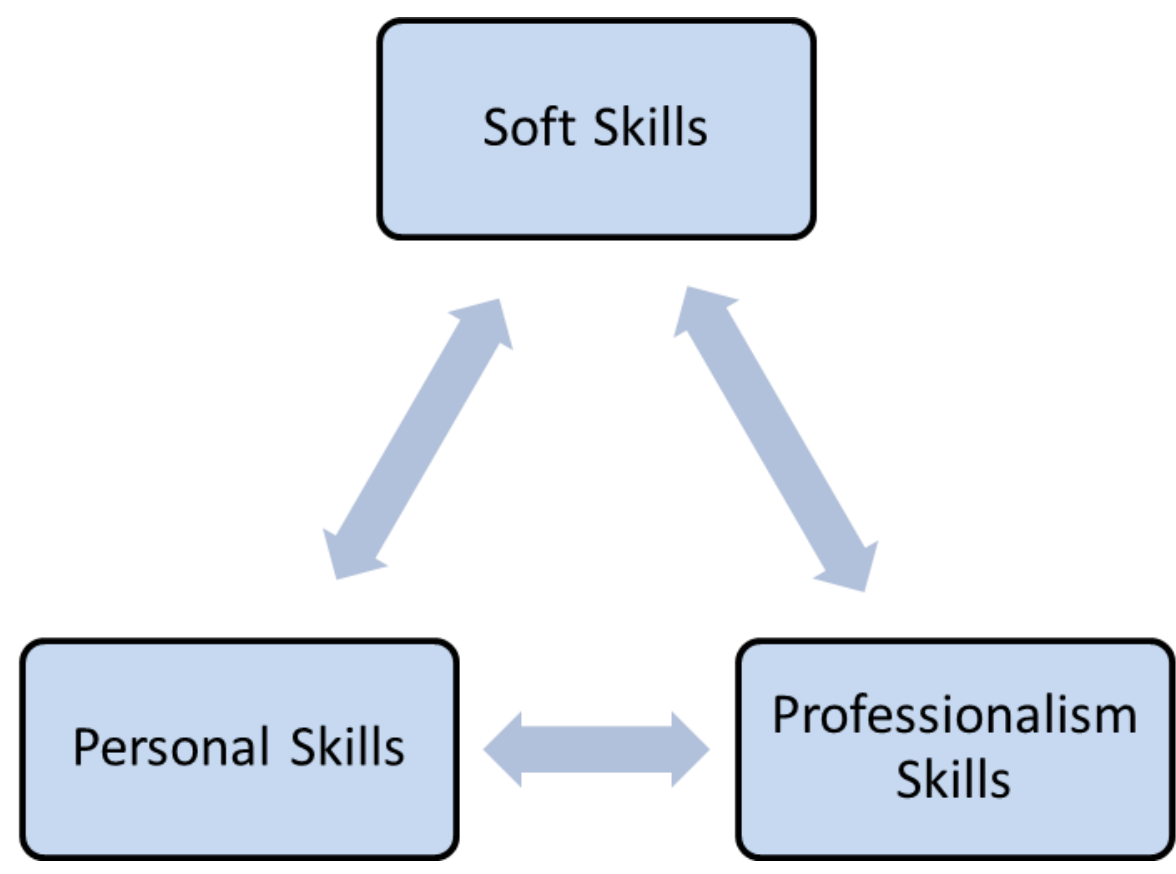

Soft Skills In Islamic Perspective

${ }^{11}$ Read http://www.thefreedictionary.com/initiative, retrieved on April 24, 2012

KHATULISTIWA: Journal of Islamic Studies Vol. 10, No. 1. March 2020
DOI: http://10.24260/khatulistiwa.v10i1.1701 The Instructional Management on Soft Skills in Islamic Persepctive: A Multi-case Study at Sekolah Karakter... 


\section{BIBLIOGRAPHY}

Arikunto, Suharsimi \& Yuliana, Lia. (2009). Manajemen Pendidikan. Aditya Media. Yogyakarta.

Glickman, C. D. 1981. Development Supervision: Alternative for Helping Teachers Improve Instructions. Virginia, Alexandria: ASCD.

Glickman, C. D., Gordon, S. P., Gordon, J. M. R. 2004. SuperVision and Instructional Leadership A Developmental Approach. Boston., Pearson.

Given, Lisa M (ed.) The Sage Encyclopedia of Qualitative Resarch Methods. Vol 1 \& 2. USA: SAGE Publications, 2008.

Endin Mujahidin, et.al., (2012). Developing Character Education Quality in Elementary School. Paper presented at the International Conference UIN Malang, December 2-3, 2012.

Gardner, H. (1999). Intelligence reframed: Multiple intelligences for the 21st century. New York: Basic Books.

Gardner, H. (1993). Multiple intelligences: The theory in practice. New York.

Goleman, D. (1995). Emotional Intelligence: Why it can matter more than IQ. New York: Bantam Books

Goleman, D. (1998). Working with emotional intelligence. New York: Bantam.

Megawangi, Ratna et al. (2011). Neuroscience for Kids: Pengendalian Emosi Anak. Seri Pendidikan Karakter. Depok. Indonesia Heritage Foundation.

Megawangi, Ratna et al. (2011). Membangun Karakter Anak melalui Brain-Based Parenting (Pola Asuh Ramah Otak). Seri Pendidikan Karakter. Depok. Indonesia Heritage Foundation.

Megawangi, Ratna and Farrah, D., Wahyu. (2011). Sekolah Berbahaya bagi Perkembangan Karakter Anak: Solusi untuk Mempersiapkan Sekolah dalam Menjalankan Pendidikan Karakter. Seri Pendidikan Karakter. Depok. Indonesia Heritage Foundation.

Musnandar, Aries (2016). The Instructional Management of Students Soft Skills In Elementary Schools: A Multi-Case Study at Sekolah Karakter Indonesia Heritage Foundation (IHF) and Sekolah Dasar Brawijaya Smart School (BSS). Dissertation. Postgraduate, Maulana Malik Ibrahim, State Islamic University.

Musnandar, Aries. 2014. Indonesia: A Country of Challenge. Malang. UB Press.

KHATULISTIWA: Journal of Islamic Studies Vol. 10, No. 1. March 2020
DOI: http://10.24260/khatulistiwa.v10i1.1701 The Instructional Management on Soft Skills in Islamic Persepctive: A Multi-case Study at Sekolah Karakter... 
Musnandar, Aries. 2013. Pendidikan yang Mencerdaskan. Malang. Naila Pustaka

Raka Joni, T. 2005. PembelajaranYang Mendidik: Artikulasi Konseptual, Terapan Kontekstual dan Verifikasi Empirik. PPs, Universitas Negeri Malang.

Sonhaji, Ahmad. 2003. Modul Manajemen Strategik. Program Pascasarjana, Universitas Negeri Malang

Sternberg, R. (2000). Handbook of Intelligence. Cambridge, UK: Cambridge : University Press. p. $396-417$

The Republic Indonesian Laws (Peraturan Perundang-Undangan):

Republik Indonesia. Undang-Undang Nomor 20 Tahun 2003 tentang Sistem Pendidikan Nasional (The Law of National Education System of the Republic of Indonesia)

Peraturan Pemerintah RI Nomor 17 Tahun 2010 tentang Pengelolaan dan Penyelenggaraan Pendidikan

Peraturan Pemerintah RI No. 19 Tahun 2005 tentang Standar Nasional Pendidikan

Barbuto Jr., John E., Burbach, Mar E. (2006). The Emotional Intelligence of Transformational. 146, Iss. 1, pg. 51, 14 pgs.

Subramaniam, Ilangko. Techers perception on their readiness in integrating soft skills in the teaching and learning. IOSR Journal of Reserach \& Method in Education Volume 2, Issue 5 (Jul.-Aug. 2013), pp 19-29.

Wellington, James (2005). The Soft skills of Success. Vital Speeches of the Day, August 1, vol 71, Iss. .20, pg. 628.7 pgs

Caudron, Shari (2006). The Hard Case for Soft skills: Bradford: Vol. 27, Iss. 2-4; pg. 202.1pg

Aries Musnandar, Taking examples of Prophet's tolerance. the Jakarta Post, February 7, 2012

Chaedar Alwasilah, Holistic education creates 'perfect people'. the Jakarta Post, 01/28/2012

C.W Watson, Learning and teaching process: More about readers and writers. Jakarta Post, $02 / 11 / 2012$

Musnandar, Aries. Pengembangan Paket Pembelajaran Presentation Skills bagi Karyawan Penyelia PT. Philip Morris Indonesia, Thesis Teknologi Pembelajaran, Program Pascasarjana UM, 2004.

Aries Musnandar, Landasan Konstruktivistik, Makalah tidak dipublikasikan, Program Pascasarjana, Universitas Negeri Malang, 2000

KHATULISTIWA: Journal of Islamic Studies Vol. 10, No. 1. March 2020
DOI: http://10.24260/khatulistiwa.v10i1.1701 The Instructional Management on Soft Skills in Islamic Persepctive: A Multi-case Study at Sekolah Karakter... 
www.eiconsortium.org

\section{www.uinmalang.}

http://cnx.org/content/m13867/latest/

http://ihf.or.id/en/elementary.asp

http://www.google.co.id/\#q=managing+soft+skills+pictures

http://mudjiarahardjo.uin-malang.ac.id/materi-kuliah/185-research-design-quantitativeand-qualitative-approach.html

KHATULISTIWA: Journal of Islamic Studies Vol. 10, No. 1. March 2020
DOI: http://10.24260/khatulistiwa.v10i1.1701 The Instructional Management on Soft Skills in Islamic Persepctive: A Multi-case Study at Sekolah Karakter... 